\section{Cigarette smoke exposure severely reduces peripheral insulin sensitivity without changing GLUT4 expression in oxidative muscle of Wistar rats}

\author{
Exposição à fumaça de cigarro reduz gravemente a \\ sensibilidade à insulina periférica sem alterar a expressão \\ de GLUT4 em músculo oxidativo de ratos Wistar
}

Patricia Ebersbach-Silva', Thamara Alves', Agatha Tomoko

Sakata Fonseca', Marcia Aparecida do Nascimento Oliveira², Ubiratan Fabres Machado², Patricia Monteiro Seraphim'

\begin{abstract}
Objective: To evaluate the effect of exposure to cigarette smoke and running training on a treadmill on the expression of glucose transporter GLUT4 in oxidative soleus muscle of rats. Materials and methods: Wistar rats were divided into: (C) control, (E) exercise control, (SS), sedentary smoker, and (ES) exercise smoker. Insulin Tolerance Test, Western blotting, and RT-PCR were performed for the evaluation of GLUT4 levels. Results: The SS group presented lower insulin sensitivity with reduced GLUT4 protein in the plasma membrane (PM), no changes in the microsomal fraction, but increased mRNA content. Training reversed this condition. No intervention altered total GLUT4 content of the oxidative muscle. Conclusion: These results suggest that passive smoking stimulates GLUT4 transcription without changing total protein content, but impairs the ability of GLUT4 translocation to the PM. On the other hand, training seems to reduce the deleterious effects, even under the influence of cigarette smoking. Arq Bras Endocrinol Metab. 2013;57(1):19-26
\end{abstract}

\section{Keywords}

Cigarette smoking; training; glucose transporter; GLUT4; insulin resistance; oxidative muscle

\section{RESUMO}

Objective: Avaliar o efeito da exposição à fumaça de cigarro e do treinamento de corrida em esteira rolante sobre a expressão do transportador de glicose GLUT4 no músculo oxidativo solear de ratos. Materiais e métodos: Ratos Wistar foram divididos em: (C) controle, (E) exercitado, (SS) fumante sedentário e (ES) fumante exercitado. Foram realizados testes de tolerância à insulina, Western Blotting e RT-PCR para avaliação da expressão de GLUT4. Resultados: 0 grupo SS apresentou menor sensibilidade à insulina, com redução de proteína GLUT4 na membrana plasmática (MP), sem alteração na fração microssomal, e conteúdo de RNAm aumentado. $\mathrm{O}$ treinamento reverteu esse quadro. Nenhuma intervenção alterou o conteúdo total de GLUT4 no músculo oxidativo. Conclusão: Esses resultados sugerem que o fumo estimula a transcrição de GLUT4 sem alterar o conteúdo total de proteína, porém prejudica a capacidade de translocação para a MP. Já o treinamento em esteira parece, mesmo sob influência do cigarro, reduzir seus efeitos deletérios. Arq Bras Endocrinol Metab. 2013;57(1):19-26

Descritores

Fumaça de cigarro; treinamento físico; transportador de glicose; GLUT4; resistência à insulina; músculo oxidativo
1 Department of Physical Therapy, School of Science and Technology, Universidade Estadual Paulista (Unesp), Sao Paulo, SP, Brazil 2 Department of Physiology and Biophysics, Institute of Biomedical Sciences, Universidade de São Paulo (USP), Sao Paulo, SP, Brazil

Correspondence to:

Patricia Monteiro Seraphim Departamento de Fisioterapia, Bloco III, Faculdade de Ciências e Tecnologia, Universidade Estadual Paulista

Rua Roberto Simonsen, 305 Centro Educacional 19060-900 - Presidente Prudente, SP, Brazil

patricia@fct.unesp.br

Received on Feb/11/2012 Accepted on Sept/2/2012 


\section{INTRODUCTION}

$\mathrm{C}$ igarette smoking has been considered a significant risk factor for many diseases, and evidence indicates that it is associated with insulin resistance and decreased glucose tolerance $(1,2)$. Smoking is related with high levels of several inflammatory markers, such as $\mathrm{C}$ reactive protein (CRP); interleukins, such IL6 , IL-1B; and tumor necrosis factor alpha (TNF- $\alpha$ ), which are associated to a chronic inflammatory process that could be the triggering factor for insulin resistance and, eventually, type 2 diabetes (3-5). Another acute effect of smoking consists of the increase in the activity of the sympathetic nervous system, generating high levels of circulating catecholamines, which are potent antagonists of insulin action, since smoking can reduce the number of binding sites for insulin, and decrease the intrinsic activity and/or synthesis of glucose transporters (6).

At the cellular level, insulin resistance is associated with a decline in the hormone signaling pathway, and is related to a reduction in the expression, or impairment in the translocation of GLUT4 glucose transporter to the plasma membrane (7). In the basal state, GLUT4 is associated to intracellular vesicles making up the microsomal membranes associated with the transgolgi apparatus and/or transverse tubules from the adipose and muscle tissue. Under insulin stimulation, GLUT4 migrates from microsomes $(\mathrm{M})$ to the plasma membrane (PM), contributing with about a $40 \%$ increase in glucose uptake (8). Studies have shown that physical activity can increase the expression of the intracellular elements of the insulin signaling pathway. Several studies suggest that exercise increases the protein GLUT4 and mRNA expression, and it has been used as a method for diabetes treatment (9-11). Muscle contraction can stimulate glucose transport by a pathway independent of the insulin signaling (12), indicating that a person who presents impaired insulin signaling pathway can improve glucose homeostasis by means of exercise training (13).

The literature lacks detailed information on smoking and GLUT4 levels in oxidative fibers as well as on the effects of training, since smokers present poor physical conditioning compared with non-smokers. So, it is relevant to investigate the processes involving insulin resistance as a result of smoking, and the associated effects of training. The analysis of GLUT4 expression can be a great clinical tool, and the knowledge about its regulatory mechanisms may provide therapeutic mea- sures for metabolic diseases, such as type 2 diabetes and insulin resistance. Thus, this study aimed to verify if the insulin resistance established in smokers may be related to changes on GLUT4 expression in oxidative skeletal muscle, and to assess the effect of regular moderate physical training on GLUT4 expression and insulin resistance of smoking rats, as a way of improving the quality of life.

\section{MATERIALS AND METHODS}

\section{Animals}

The study was approved by the local Research Ethics Committee, according to the "Ethical Principles in Animal Experimentation" (COBEA), process $\mathrm{n}^{\mathrm{O}}$ $262 / 2008$.

Male Wistar rats were kept in cages under controlled conditions, $22 \pm 2^{\circ} \mathrm{C}$, on a 12:12-h light-dark cycle (7:00 am - 7:00 pm/7:00 pm - 7:00 am), and were fed with standard rodent chow (Supra Lab, Alisul Ind. Alimentos. Ltda., RS, Brazil) and water ad libitum.

Animals were divided into 4 groups: sedentary control group (S), exercise control group (E), sedentary smoking group (SS), and exercise smoking group (ES). The SS and ES groups were exposed to the combustion of four cigarettes for 30 minutes, twice a day, 5 days a week, during 8 weeks. A closed box divided in two compartments was used as the inhalation chamber. One of the compartments was used to arrange the four cigarettes in a holder, and the other one was used for the exposure of 10 animals. A $10 \mathrm{~L} / \mathrm{min}$-air compressor was connected to the cigarette compartment and pushed the smoke to the other side of the box. The compartment for the animal presented a hole for the exhaust smoke. This dose of smoke exposure is equivalent to 10 to 20 cigarettes for a chronic human smoker (14).

The E and ES groups followed a regular moderate exercise protocol on a treadmill for small animals. The treadmill was powered by a $12 \mathrm{~V}$ motor, which provided a speed of 9.75 meters per minute, and the experimental protocol was performed during 8 weeks, 5 days a week, for 60 minutes. This training consisted of moderate exercise, without increases in intensity or duration.

\section{Insulin tolerance test}

For the evaluation of in vivo insulin sensitivity, animals were submitted to an insulin tolerance test (ITT) after 4 hours of fasting. Tail vessel blood samples were 
collected before the procedure $(0 \mathrm{~min})$, and at 5,10 , 15 , and 20 minutes after an intravenous injection of regular insulin $\left(0.5 \mathrm{UKg}^{-1}\right.$, Novolin, Novo Nordisk, Denmark). Blood glucose was measured using specific test strips and a glucometer (Biocheck TD-4225/ Bioeasy Diagnostics Ltda./MG - Brazil). Results were analyzed by comparing the rate constant for glucose disappearance (kITT) from 0 to 20 minutes of the test, based on linear regression of the Napierian logarithm of glucose concentrations.

\section{Tissue and blood samples}

After 24 hours of the last training session, animals were anesthetized i.p. with ketamine and xylazine hydrochloride $(60 \mathrm{mg} / \mathrm{kg}$ of body weight). Samples of blood and soleus oxidative skeletal muscle were collected.

\section{Western Blotting}

To evaluate the expression of GLUT4 protein, soleus muscle was homogenized and separated in two fractions of cell membranes: plasma membrane (PM) and microsome $(\mathrm{M})$. Briefly, soleus muscle was homogenized in buffer containing $7.4 \mathrm{pH} 10 \mathrm{mmol} / \mathrm{L}$ TRIS HCl, 1 $\mathrm{mmol} / \mathrm{L}$ EDTA, $250 \mathrm{mmol} / \mathrm{L}$ sucrose, and centrifuged at $760 \mathrm{~g}$ for 10 minutes at $4^{\circ} \mathrm{C}$. The supernatant was kept, and the pellet resuspended in the same buffer and submitted to another centrifugation $(760 \mathrm{~g})$ for 10 minutes at $4^{\circ} \mathrm{C}$. The two supernatants were submitted to another centrifugation cycle at $31,000 \mathrm{~g}$ for $60 \mathrm{mi}-$ nutes at $4^{\circ} \mathrm{C}$. The pellet, corresponding to the plasma membrane fraction (PM), was resuspended in buffer and stored at $-20^{\circ} \mathrm{C}$ until the analysis. The supernatant was submitted to ultracentrifugation $(190,000 \mathrm{~g})$ for 60 minutes at $4^{\circ} \mathrm{C}$. The pellet, corresponding to the microsomal fraction $(\mathrm{M})$, was resuspended in buffer and stored at $-20^{\circ} \mathrm{C}$.

Total protein concentration was measured by LOWRY method (15), and the amount of GLUT4 protein detection was performed using polyacrilamyde gel electrophoresis (SDS-PAGE) and chemiluminescence (ECL) for the detection of bands. Equal amounts of protein were solubilized in Laemmli buffer, submitted to SDS-PAGE (10\%), and then electrophoretically transferred to a nitrocellulose membrane Hybond-C Super (GE Healthcare, New York, USA).

Non-specific protein binding was reduced by means of a blocking buffer (non-fat powdered milk diluted in PBS $1 \mathrm{x}$ at $7.4 \mathrm{pH}$ ) for $\mathrm{l} \mathrm{h}$. After that, membranes were incubated with anti-GLUT4 antibody (Chemicon International, Temecula California, USA), diluted 1:3,000 in $1 \times$ PBS $/ \mathrm{BSA} 8 \%$ for 3 hours at $37^{\circ} \mathrm{C}$. Then, they were incubated with a secondary antibody (anti-rabbit IgG), labeled with peroxidase (HRP; GE Helthcare, Amersham, UK) diluted 1:6,000 in blocking solution for 1 hour $(5 \%$ powdered milk $+20 \mathrm{~mL}$ of 1 X PBS $+0.05 \%$ Tween 20). The membrane was washed vigorously with lx PBS and placed in contact with $5 \mathrm{~mL}$ of the chemiluminescence reagent (Luminol 1.1\% acid, P-coumaric acid $0.48 \%, 1 \mathrm{M}$ Tris ( $\mathrm{pH} 8.5$ ), $11.1 \%, \mathrm{H}_{2} \mathrm{O}$ distilled) for 2 minutes, and then exposed to hyperfilms ${ }^{\circledR}$ (IGF - Corporation, New Jersey, USA) for the detection of the bands. The film was photographed in a photodocumentation equipment (Model 100 Gel Logic, epi-iluminescence, Kodak Molecular Imaging, USA), and images were analyzed by densitometry using Scion Image for Windows software (Scion Corporation, USA).

RT-PCR. For RT-PCR, total RNA from the muscle was extracted using Trizol Reagent (Invitrogen, USA), following the manufacturer's instructions. Five micrograms of total RNA were submitted to the reverse transcription reaction (RT) with random primers. Enzyme buffer ( $50 \mathrm{mM}$ Tris- $\mathrm{HCl} \mathrm{pH} 8.3,75 \mathrm{mM} \mathrm{KCl}$, $3 \mathrm{mM} \mathrm{MgCl}$ ), DTT (10 mM), dNTPs mix $(0.5 \mathrm{mM}$ each), random primers (150 ng), RNase inhibitor (40 $\mathrm{U})$, and enzyme M-MLV reverse transcriptase (200 U/ $\mu \mathrm{L}$, Invitrogen, USA) were added to each sample. This mixture was denatured at $65^{\circ} \mathrm{C}$ for $5 \mathrm{~min}$, and then incubated at $42^{\circ} \mathrm{C}$ for $60 \mathrm{~min}$. After this period, reactions were incubated at $70^{\circ} \mathrm{C}$ for $15 \mathrm{~min}$ for the amplification of the fragments. Aliquots of $1 \mu \mathrm{L}$ of RT final products (cDNA) were added to $10 \mathrm{pmol} / \mu \mathrm{L}$ of $S l c 2 a 4$-specific primers (Sense: 5'-CCCCTCCAGGGCAAAGGAT-3', Antisense: 5'-TCCTGGAGGGGAACAAGAA-3' Size: $203 \mathrm{bp}$, annealing temperature: $54^{\circ} \mathrm{C}, 28$ cycles), and constitutive protein $A c t b$ was used for normalization (Sense: 5'-ATGAAGATCCTGACCGAGCGTG-3', Antisense: 5'-CTTGCTGATCCACATCTGCTGG-3'; Size: $512 \mathrm{bp}$, annealing temperature: $54^{\circ} \mathrm{C}, 24$ cycles). Each amplification reaction was performed in the presence of the enzyme 5X Colorless Green GoTaq Flexi Buffer (Promega, USA), $\mathrm{MgCl}_{2}(25 \mathrm{mM})$, dNTPs mix (10 mM either), GoTaq DNA polymerase $5 \mathrm{U} / \mathrm{mL}$ (Promega, USA), primers (sense and antisense, $10 \mathrm{mM}$ each), $1 \mu \mathrm{L}$ samples of PCR product, and Milli-Q water, as suggested by the manufacturer (Promega, USA). PCR reactions were performed with an initial step of denaturation of cDNA template at $95^{\circ} \mathrm{C}$ for $2 \mathrm{~min}$. The 
next denaturarion cycles were performed at $95^{\circ} \mathrm{C}$ for $30 \mathrm{~s}$; annealing at specific temperatures for each primer, as previously described; and extension at $72^{\circ} \mathrm{C}$ for $30 \mathrm{~s}$.

Finally, the material was cooled at $4^{\circ} \mathrm{C}$. The amplified products were submitted to electrophoresis in agarose gel with ethidium bromide for viewing and analysis under UV light. The images were captured in an appropriated apparatus (Mod Gel Logic 100, Kodak Molecular Imaging, USA).

\section{Statistical analysis}

All data are presented as means \pm SEMs. Values for the sedentary group $(S)$ were adjusted to $100 \%$ in experiments of total content of GLUT4 protein and mRNA. Data were analyzed using one-way analysis of variance (ANOVA) with Bonferroni post-hoc test, if necessary. Differences among groups were considered significant when $P$ value was less than 0.05 .

\section{RESULTS}

\section{Morphometric and serum analysis}

Morphometric and serum analysis are shown in table 1. All animals presented similar body and periepididymal fat pad weight, but the E group presented increased soleus muscle weight compared with the others, suggesting that regular, moderate exercise promoted gain in lean mass only in the non-smoker group.

There was no change in fasting plasma glucose levels among the groups. Insulin sensitivity was assessed by means of ITT, and the results showed that the rate constant of plasma glucose disappearance (kITT) was significantly reduced by $40 \%$ in the SS group compared with the $S$ group, and by $60 \%$ compared with the ES group. On the other hand, regular, moderate exercise improved this condition both in sedentary and smoker groups, with a $42 \%$ and $128 \%$ increase, respectively, suggesting great benefit of regular training in improving insulin sensitivity in this model.

\section{GLUT4 expression in soleus muscle}

In order to verify the effect of smoke exposure and exercise on GLUT4 expression, we evaluated Slc2a4 mRNA and protein expression in soleus muscle.

We detected a significant increase of $31 \%$ in the $\mathrm{E}$ group, and 28\% in the SS group compared with the $S$ group in Slc2a4 mRNA content (Figure 1).

In contrast, Figures $2 \mathrm{~A}$ and $2 \mathrm{~B}$ show that the total amount of GLUT4 protein content in plasma membrane $(\mathrm{PM})$ per gram of tissue was reduced in the SS group compared with the $S\left(34 \%,{ }^{*} \mathrm{P}<0.05\right)$ and the $\mathrm{E}(43 \%, \mathrm{P}<0.05)$ groups, and significantly increased in the ES group compared with the SS group. The results

A

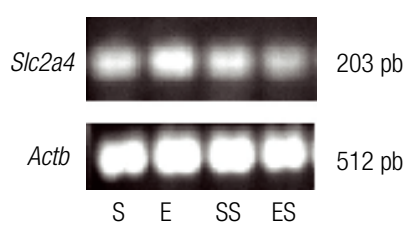

B



Figure 1. Slc2a 4 mRNA expression in soleus muscle: $5 \mu \mathrm{g}$ of total RNA were submitted to RT-PCR, as described in the methods section. (A) Representative images of glucose transporter GLUT4 and constitutive Actb obtained by RT-PCR. (B) GLUT4 mRNA expression was corrected by Actb mRNA expression. The results were expressed as arbitrary units $(\mathrm{AU})$, and the values are mean \pm standard error of mean (SEM), ${ }^{*} \mathrm{P}<0.05$ vS. S. N: 10 different assays and animals for each group; S: sedentary control group; E: exercise control group; SS: sedentary smoker group; ES: exercise smoker group. (S: $100 \pm 10.7$, E: $130.9 \pm 7.7^{*}$; SS: $128.5 \pm 6.9^{*}$; ES: $121.5 \pm 7.7$, results expressed as $A U, n=10$ animals each group, ${ }^{*} P$ $<0.05$ vs. S).

Table 1. Serum profile and morphometric features of the animals

\begin{tabular}{llcccc}
\hline Group & $\begin{array}{c}\text { Body } \\
\text { weight }(\mathbf{g})\end{array}$ & $\begin{array}{c}\text { Soleus } \\
\text { weight }(\mathbf{g})\end{array}$ & Adipose weight (g) & $\begin{array}{c}\text { Blood glucose } \\
(\mathbf{m g} / \mathbf{d L})\end{array}$ & kITT (\%/min) \\
\hline S & $364.77 \pm 9.7(n=18)$ & $0.16 \pm 0.007(n=18)$ & $3.37 \pm 0.40(n=12)$ & $148 \pm 10(n=15)$ & $3.7 \pm 0.3(n=6)$ \\
& $372.42 \pm 7.2(n=21)$ & $0.20 \pm 0.008^{*}(n=21)$ & $3.22 \pm 0.37(n=13)$ & $131.5 \pm 7(n=19)$ & $5.28 \pm 0.5^{*}(n=6)$ \\
E & $368.95 \pm 6.7(n=21)$ & $0.18 \pm 0.005(n=21)$ & $3.92 \pm 0.31(n=13)$ & $139.5 \pm 9.6(n=18)$ & $2.1 \pm 0.7^{* \#}(n=6)$ \\
SS & $376.42 \pm 7.8(n=21)$ & $0.18 \pm 0.005(n=21)$ & $2.85 \pm 0.21(n=14)$ & $130.6 \pm 10.2(n=18)$ & $4.8 \pm 0.1^{* \&}(n=3)$ \\
\hline
\end{tabular}

Data are presented as mean \pm SEM. The number of animals is in parenthesis ${ }^{*} P<0.05$ vs. S, ${ }^{\#} P<0.02$ vs. E, ${ }^{\circledR} P<0.05$ vs. SS. S: sedentary control group; E: exercise control group; SS: sedentary smoker group; SS: exercise smoker group. 
for total amount of GLUT4 protein content per gram of tissue in microsomes (Figures 2C and 2D) showed an important increase $(\sim 75 \%)$ in all groups compared with the $S$ group, although no statistical difference was detected.

Figure 2E shows the sum of GLUT4 protein content in both cellular fractions, $\mathrm{PM}+\mathrm{M}$, making up total GLUT4 protein content found in skeletal soleus muscle for glucose uptake. We can observe that the $S$ and SS groups had similar GLUT4 protein levels. Regular, moderate exercise, on the other hand, provoked a similar increase of GLUT4 protein amount in skeletal oxidative muscle, in both smoking (SS) and non-smoking animals (E).
A

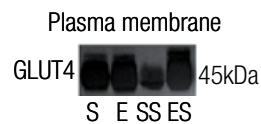

B


C Microssomal membrane

GLUT4 HEDTC 45Ka $S$ ESSES

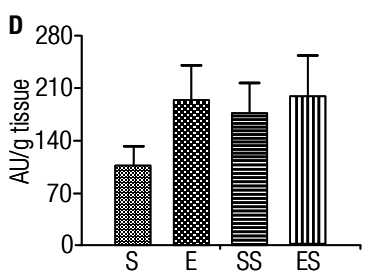

Figure 2. GLUT4 protein content in soleus muscle: $20-30 \mu \mathrm{g}$ of protein were submitted to immunoblotting and electrophoresis as described in the methods section. (A) Typical autoradiogram of GLUT4 in plasma membrane obtained by Western blotting assay. (B) Results shown as means \pm SEMs, expressed in arbitrary units per gram of tissue (S: 101.61 \pm 7.8 ; E: $116.60 \pm 12.21$; SS: $66.37 \pm 10.06^{\star 2}$; ES: $125.42 \pm 19.63^{\#}$ $\mathrm{AU} / \mathrm{g}$ tissue, ${ }^{*} \mathrm{P}<0.05$ vs. S; \& $\mathrm{P}<0.05$ vs. $\mathrm{E} \# \mathrm{P}<0.05$ vs. SS). (C) Typical autoradiogram of the GLUT4 expression in microsomal membrane obtained by Western blotting assay. (D) Results shown as means \pm SEMs, expressed as arbitrary units per gram of tissue (S: $101.23 \pm 25.4$; E: $199.54 \pm$ 47.02; SS: $175.25 \pm 38.07$; ES: $214.83 \pm 66.6$ AU/g tissue). (E) Total content of glucose transporter GLUT4. ( $\mathrm{S}=207.7 \pm 21.1$; $\mathrm{E}=$ $351.6 \pm 52.6^{*} ; \mathrm{SS}=206.5 \pm 43.3 ; \mathrm{ES}=329.2 \pm 71.6 ;{ }^{*} \mathrm{P}<0.05$ vs. S) $\mathrm{N}=10$ different assays and animals for each group. S: sedentary control group; E: exercise control group; SS: sedentary smoker group; ES: exercise smoker group. ANOVA and Bonferroni as post-hoc test were used in the comparison.

\section{DISCUSSION}

Cigarette smoking is an important risk factor for many diseases and, recently, it has been associated to insulin resistance and diminished glucose tolerance, which could culminate in development of type 2 diabetes $(1,2)$. On the other hand, literature shows that physical exercise has been recommended to prevent and treat insulin resistance and type 2 diabetes, since it increases glucose uptake in muscle in a pathway independent of insulin signaling (16). In this context, this study aimed to investigate the effects of cigarette smoking on insulin resistance, focusing on glucose transporter expression in oxidative muscle, and the consequences of physical training in smokers. Various studies focusing on the exposure to cigarette smoke and/or effect of training associated with smoking have shown effects on the lungs (17). This is a rare study evidencing the effects of the exposure to cigarette smoke on skeletal muscle and tissue insulin resistance of smokers.

This study pointed out that cigarette smoke did not change the morphometric profile of the animals. However, it impaired insulin sensitivity in the rats. Besides, the exposure to cigarette smoke provoked increase in mRNA levels without increasing protein content, suggesting that cigarette smoke causes some defect on the translation machinery of this gene, as we observed in other animal models of insulin resistance (18). However, when smoking animals were submitted to the training protocol, insulin sensitivity, and mRNA and protein levels were correlated. Considering the isolated fraction of cellular membranes (PM and $\mathrm{M}$ ), we found that, although the exposure to cigarette smoke has affected GLUT4 protein content in PM, the content in $\mathrm{M}$ fraction did not change. Training has contributed to improve GLUT4 protein content compared with the sedentary group in general, mainly correcting the impairment caused by smoking.

In the literature, it is known that nicotine can increase energy expenditure and reduce appetite and palatability, which explains why smokers tend to have lower body weight compared with non-smokers. People who quit smoking may often gain weight, since they increase calorie intake and modify tissue metabolism (19). Similar to the literature, the weight of the animals did not change among the groups (Table 1) in the present study, probably because the smoke exposure period ( 8 weeks) was not long enough to provoke an impairment in food intake (data not shown) 
or food palatability. However, WAGER-SRDAR (20) found that weight and food intake of rats exposed to cigarette smoke for only 14 days were suppressed compared with animals that were not exposed. But the dose of exposure was very high compared with the present study. On the other hand, Azzalini and cols. (21) did not find changes in this parameter in Zucker rats treated in a similar inhalation chamber and 4-week exposure schedule. Thus, it seems that, depending on the dose of cigarette smoke exposure, body weight and food intake may either change or not. There is evidence that cigarette smoking does not result in greater weight gain, but it favors visceral fat accumulation (increase in waist-hip ratio), which could contribute to the installation of insulin resistance and/or development of type 2 diabetes (19). In spite of this, the present study did not detect changes in the distribution of visceral fat mass or any change in fat mass weight in smoker rats either.

Various studies have shown that active or passive smoking is associated with impaired glucose tolerance $(19,20,22)$. Although, in this study, we did not find any changes in fasting blood glucose after exposure to cigarette smoke (Table 1), an assessment of insulin sensitivity in vivo was carried out with the ITT. Considering the results, it was observed that exposure to cigarette smoke caused a significant reduction in insulin sensitivity in the SS group. It has been considered that decreased insulin sensitivity among smokers may be due to the direct effects of nicotine, carbon monoxide, or other components of tobacco. Alternatively, long-term cigarette smoking may lead to vascular changes that reduce blood flow to skeletal muscles and, therefore, causes a decrease in glucose uptake mediated by insulin due to reduced glucose arrival in this tissue (23). On the other hand, literature shows that physical exercise has been recommended for the prevention and treatment of insulin resistance and type 2 diabetes (16). In this study, it was possible to confirm that exercise training can lead to improved insulin action, since the ES group presented a $128 \%$-higher kITT compared with SS. Furthermore, exercise per se has increased insulin sensitivity of the animals, highlighting how beneficial the practice of exercise can be.

The analysis of Slc2a4 mRNA content in the soleus muscle (Figure 1) showed significant increase in glucose transporter transcription in the SS compared with the $S$ group. Interestingly, this reflects that smoking may be upregulating $S l c 2 a 4$ transcription in the oxidative muscle, probably because of its characteristics. The red fibers (soleus) present more mitochondria and higher oxidative capacity when compared with white fibers, and thus can be more sensitive to hypoxia caused by smoking. Literature shows that stimuli causing reduced blood oxygen can contribute to an increase in Slc2a4 transcription, since it activates hypoxia inducible factor 1- $\alpha$ (HIFl- $\alpha$ ) (24). An and cols. (25) demonstrated an activation of 5 ' adenosine monophosphate-activated protein kinase (AMPK) in 3T3Ll adipocytes culture incubated with nicotine. Therefore, in the present study, it is possible that the exposure to cigarette smoke may have stimulated the activation of these proteins, which evoked a positive regulation of $\operatorname{Slc} 2 a 4$ transcription (26). An in vitro study (24) showed that contraction rapidly increases Slc2a4 mRNA content, which is accompanied by an increase in the level of transcriptional factors, such as MEF2A, MEF2D, and HIFl- $\alpha$. Additionally, literature has shown that physical exercise is an important physiological stimulus to increase $S l c 2 a 4$ mRNA expression, highlighting AMPK as an initiator of a cascade of intracellular events $(26,27)$. In the present study, we observed a positive effect of training in Slc2a 4 mRNA in soleus muscle (Figure 4), but additional analyses are necessary to understand which transcription factor may be involved.

Analyzing GLUT4 protein content in plasma membrane (PM) and microsomal (M) fractions, we found that smoking caused a significant reduction in PM (Figure $2 \mathrm{~B}$ ) and simultaneous increase of the $\mathrm{M}$ fraction (Figure 2D), compared with the nonsmoker sedentary group. On the other hand, the analysis of GLUT4 total protein content showed that, although there is no correlation between mRNA and protein levels, in fact, smoking did not impair GLUT4 translation in the oxidative muscle. But, according to the literature $(3,5,28)$ cigarette smoking seems to interfere in the translocation event, although the mechanisms involved in this event are not fully indentified. Some studies have suggested a group of proteins that could be the responsible for this alteration, since smoking causes inflammation and oxidative stress (29), and incubation of muscle cells with nicotine and palmitate $(28)$ culminates in the activation of the PKC $\theta$ (protein kinase C, type $\theta$ ), NF-kB (nuclear factor kappa B) and TNF- $\alpha$ (tumor necrosis factor alpha), which could impair GLUT4 translocation to the plasma membrane. In the present study, we did not analyze the capacity of GLUT4 translocation; however, the overall results contribute to suggesting that translocation could be impaired in this model of insulin resistance. 
The present study also showed that moderate treadmill training is efficient in increasing GLUT4 protein content in both smokers (ES) and nonsmokers (E), especially in the PM fraction (Figure 2B). Assessing total GLUT4 content (Figure 2E), it is evident that physical exercise has a fundamental role in increasing GLUT4 protein levels, which could reflect greater capacity of glucose uptake, and improvement in the management of glucose homeostasis, independent of smoking. The combination of insulin and exercise results in additive effects on glucose transport associated to GLUT4 recruitment to the plasma membrane, confirming the hypothesis of the stimulation of two different mechanisms involving two distinct intracellular pools of glucose transporters, one responsive to exercise and the other, to insulin (30), involving PI3-k and AMPK, respectively $(30,31)$. Thus, our results are in agreement with literature data, with positive effects even for smokers.

Another limitation of the present study was to obtain a trustworthy method for measuring the real dose of smoke received by each animal in the experiment, but the dose used in this study was determined by other studies, which reported that this exposure protocol was equivalent to the human dose for chronic smokers who consume 10 to 20 cigarettes per day (32).

Finally, we know that physical exercise is an important tool in the treatment of patients with insulin resistance and type 2 diabetes, since it improves insulin sensitivity and glucose tolerance. However, specifically for smokers, it could be the cheapest and easiest way to obtain a better quality of life, and reverse the deleterious effects of smoking on glucose homeostasis.

We concluded that cigarette smoke severely reduces insulin sensitivity, which can be reversed with treadmill training. Interestingly, smoking stimulates the transcription of $S l c 2 a 4$ gene without changing total protein content, but it seems to impair GLUT4 translocation ability in oxidative muscle, which could compromise glucose homeostasis.

Treadmill training, in turn, seems to improve transcription and to maintain GLUT4 translation in the oxidative muscle, even under the influence of cigarette smoking, being an important method to fight the harmful effects of passive smoking.

Acknowledgments: special thanks to Prof. Dr. Jose Carlos Camargo Filho and Prof. Dr. Luiz Carlos Marques Vanderlei for providing some of the equipment necessary for the study (treadmill and inhalation chamber). This study was supported by Fundação de Amparo à Pesquisa do Estado de São Paulo (Fapesp) process $\mathrm{n}^{\circ}$ 2004/10130-0; PES, TA and ATSF were recipients of a Fapesp grant (process $n^{\circ} 2008 / 01955-6 ; 2008 / 10886-8$; 2008/09328-0). TSE.

Disclosure: no potential conflict of interest relevant to this article was reported.

\section{REFERENCES}

1. Weitzman $M$, Cook S, Auinger P, Florin TA, Daniels S, Nguyen M, et al. Tobacco smoke exposure is associated with the metabolic syndrome in adolescents. Circulation. 2005;112:862-9.

2. Sairenchi T, Isso $H$, Nishimura A, Hosoda T, Irie F, Saito $Y$, et al. Cigarette smoking and risk of type 2 diabetes mellitus among middle-aged and elderly Japanese men and women. Am J Epidemiol. 2004;160:158-62.

3. Yang SR, Chida AS, Bauter MR, Shafiq N, Seweryniak K, Maggirwar SB, et al. Cigarette smoke induces proinflammatory cytokine release by activation of NF-kB and posttranslational modifications of histone deacetylasein macrophages. Am J Physiol Lung Cell Mol Physiol. 2006;291:L46-57.

4. De Luca C, Olefski JM. Inflammation and insulin resistance. Febs Letters. 2008;582:97-105.

5. Yanbaeva DG, Dentener MA, Creutzberg EC, Wesselin G, Wouters EFM. Systemic effects of smoking. Chest. 2007;131:1557-66.

6. Eliasson B, Attvall S, Taskinen MR, Smith U.The insulin resistance syndrome in smokers is related to smoking habits. Arterioscler Thromb Vasc Biol. 1994;14:1946-50.

7. Shulman GI. Cellular mechanisms of insulin resistance. J Clin Invest. 2000;106:171-6.

8. Machado UF, Schaan BD, Seraphim PM. Transportadores de glicose na síndrome metabólica. Arq Bras Endocrinol Metab. 2006;50:177-89.

9. Teran-Garcia M, Rankinen T, Koza RA, Rao DC, Bouchard C. Endurance training-induced changes in insulin sensitivity and gene expression. Am J Physiol Endocrinol Metab. 2005; 288:1168-78.

10. Holmes B, Dohm GL. Regulation of GLUT4 gene expression during exercise. Med Sci Sports Exerc. 2004;36:1202-6.

11. Thorell A, Hirshman MF, Nygren J, Jorfeldt L, Wojtaszewski JFP, Dufresne SD, et al. Exercise and insulin cause GLUT-4 translocation in human skeletal muscle. Am J Physiol Endocrinol Metab. 1999;277:E733-41.

12. Goodyear LJ. AMP-activated protein kinase: a critical signaling intermediary for exercise-stimulated glucose transport? Exerc Sport Sci Rev. 2000;28:113-6.

13. Christ-Roberts CY, Pratipanwatr T, Pratipanawatr W, Berria R, Belfort R, Kashyap $S$, et al. Exercise training increases glycogen synthase activity and GLUT4 expression but not insulin signaling in overweight nondiabetic and type 2 diabetic subjects. Metabolism. 2004;53:1233-42.

14. Wright JL, Churg A. A model of tobacco smoke-induced airflow obstruction in the guinea pig. Chest. 2002;121(5 Suppl):188S-91S.

15. Lowry $\mathrm{OH}$, Rosebrough NJ, Farr $A L$, Randall JR. Protein measurement with the Folin phenol reagent. J Biol Chem. 1951;193: 265-75.

16. Henriksen EJ. Exercise effects of muscle insulin signaling and action invited review: effects of acute exercise and exercise training on insulin resistance. J Appl Physiol. 2002;93:788-96.

17. Yu Y-B, Liao Y-W, Su K-H, Chang T-M, Shyue S-K, Kou YR, et al. Prior exercise training alleviates the lung inflammation induced by subsequent exposure to environmental cigarette smoke. Acta Physiol. 2012;205:532-40. 
18. Seraphim PM, Nunes MT, Giannocco G, Machado UF. Age related obesity-induced shortening of GLUT4 mRNA poly(A) tail length in rat gastrocnemius skeletal muscle. Mol Cell Endocrinol. 2007;276(1-2):80-7.

19. Chiolero A, Faeh D, Paccaud F, Cornuz J. Consequences of smoking for body weight, body fat distribution, and insulin resistance. Am J Clin Nutr. 2008;8:801-9.

20. Wager-Srdar SA, Levine AS, Morley JE, Hoidal JR, Niewoehner DE. Effects of cigarette smoke and nicotine on feeding and energy. Physiol Behav. 1984;32:389-95.

21. Azzalini L, Ferrer E, Ramalho LN, Moreno M, Domínguez M, Colmenero J, et al. Cigarette smoking exacerbates nonalcoholic fatty liver disease in obese rats. Hepatology. 2010;51:1567-76.

22. Eliasson B, Attvall S, Taskinen MR, Smith U. Smoking cessation improves insulin sensitivity in healthy middle-aged men. Eur J Clin Invest. 1997;27:450-6.

23. Henkin L, Zaccaro D, Haffner S, Karter A, Rewers M, Sholinsky P, et al. Cigarette smoking, environmental tobacco smoke exposure and Insulin Sensitivity: the Insulin Resistance Atherosclerosis Study. Ann Epidemiol. 1999;9:290-6.

24. Silva JLT, Giannocco G, Furuya DT, Lima GA, Moraes PAC, Nachef $\mathrm{S}$, et al. NF-kappaB, MEF2A, MEF2D and HIF1-a involvement on insulin- and contraction-induced regulation of GLUT4 gene expression in soleus muscle. Mol Cell Endocrinol. 2005;240:82-93.

25. An Z, Wang $H$, Song $P$, Zhang $M$, Geng $X$, Zou MH. Nicotine-induced activation of AMP-activated protein kinase inhibits fatty acid synthase in 3T3L1 adipocytes: a role for oxidant stress. J Biol Chem. 2007;282:26793-801.

26. Mcgee SL, Van Denderen BJ, Howlett KF, Mollica J, Schertzer JD, Kemp BE, et al. AMP-activated protein kinase regulates GLUT4 transcription by phosphorylating histone deacetylase 5. Diabetes. 2008;57:860-7.

27. Mcgee SL, Hargreaves M. Exercise and skeletal muscle glucose transporter 4 expression: molecular mechanisms. Clin Exp Pharmacol Physiol. 2006;33:395-9.

28. Morita T, Terada E, Tatebe J, Yoshino G, Saji T, Yamazaki J. Nicotine impaires GLUT4 translocation in skeletal muscle cells through mechanisms involving oxidative stress/PKC theta/nuclear factorkB/AKT pathway. J Clin Lipidol. 2008;2:S19-20.

29. Tang GJ, Wang HY, Wang JY, Lee CC, Tseng HW, Wu YL, et al. Novel role of AMP-activated protein kinase signaling in cigarette smoke induction of IL-8 in human lung epithelial cells and lung inflammation in mice. Free Radic Biol Med. 2011;50:1492-502.

30. Jessen N, Goodyear L. Contraction signaling to glucose transport in skeletal muscle. J Appl Physiol. 2005;99:330-7.

31. Jones JP, Dohm GL. Regulation of glucose transporter GLUT-4 and hexokinase II gene transcription by insulin and epinephrine. Am J Physiol Endocrinol Metab. 1997;273:E682-7.

32. Mello PRB, Okay TS, Dores EFGC, Botelho C. Marcadores de exposição tabágica em ratas lactantes utilizando um modelo de exposição passiva desde o início da gestação. Pulmão. 2005;14:289-93. 